Halai Viktoriia,

$\mathrm{PhD}$ (Law Sciences), Associate Professor, Kyiv National University of Trade and Economics, 19, Kyoto str., Kyiv, 02156, Ukraine

ORCID: 0000-0003-1568-5068

\title{
PRINCIPLE OF THE RULE OF LAW AND ITS FORMATION IN ACCORDANCE WITH THE PRACTICE OF THE EUROPEAN COURT OF HUMAN RIGHTS
}

The rule of law as a common factor in European states influences the development of international relations. The recognition of the principle of the rule of law and the enjoyment of human rights and fundamental freedoms can be traced in international instruments, in particular the interpretation and application of the provisions of the Convention for the Protection of Rights and Fundamental Freedoms.

The interpretation of the "rule of law» in the Decision of the Constitutional Court of Ukraine created the conditions for its implementation in law-making and lawenforcement activities, in particular in the laws of Ukraine. Important manifestations of the application of the principle of the rule of law have been the creation of national mechanisms for the enforcement of judgments of the European Court of Human Rights, in particular the use of decisions of this court by courts of all levels, taking into account the necessary level of independence, as well as the use of social regulators, including norms of morals and traditions. All the elements of the rule of law are closely linked. And if legal uncertainty is allowed, it will contribute to the violation of law and arbitrariness, in particular by public service bodies. At the same time, many decisions of the European Court of Human Rights contain interpretations of certain elements of the principle of the rule of law, which must certainly be reflected in the legislation of Ukraine, since, in accordance with the latter, the principle of the rule of law is applied in the light of the case law of the European Court of Human Rights.

Key words: principle, rule of law, practice, European Court of Human Rights.

Галай Вікторія. Формування принципу верховенства права з урахуванням практики Свропейського суду з прав людини.

Верховенство права як спільний чинник європейських держав впливає на розвиток міжнародних відносин. Визнання принципу верховенства права та здійснення прав людини і основних свобод можна прослідкувати у міжнародних документах, зокрема ие стосується тлумачення та застосування положень Конвениії про захист прав і основоположних свобод. 
Тлумачення «верховенства права» у Ріменні Конституційного Суду Украӥни створило у подальшому умови для втілення його у правотворчу та правозастосовну діяльність, зокрема у закони Украӥни. Важливими проявами застосування принципу верховенства права стало створено національні механізми виконання рімень Європейського суду з прав людини, зокрема використання рімень иього суду судами усіх рівнів, з урахуванням необхідного рівня незалежності, а також використання соиіальних регуляторів, зокрема норм моралі, традииій. Усі елементи верховенства права тісно пов'язані між собою. I якщо допустити юридичну не визначеність це сприятиме $i$ порушенню законності, і свавіллю, зокрема органами публічної служби. Водночас, чимало рішень Свропейського суду з прав людини вмішує тлумачення окремих елементів принципу верховенства права, що безумовно має мати відображення і в законодавстві України, оскільки, відповідно до останнього принцип верховенства права застосовується з урахуванням практики Свропейського суду з прав людини.

Ключові слова: принцип, верховенство права, практика, Свропейський суд з прав людини.

Relevance of the research topic. The principle of the rule of law in a democratic society must, at the level of national law, guarantee everyone the right to defend and to complain of wrongdoing by the public service. The practical implementation of the rule of law by state and local government representatives is impossible without the use of international human rights experience.

Formulation of the problem. An important step in the formation of the rule of law and its practical implementation is the application of the case law of the European Court of Human Rights.

The case law of the European Court of Human Rights for the formation and definition of the rule of law is important because it helps to form a practical basis for its application by the state and society. Thus, there must be a remedy in national law against arbitrary interference by public authorities. The law should contain fairly clear and precise wording that would give citizens a fair idea of the circumstances and conditions under which public authorities are empowered to take action.

Analysis of recent research and publications. The doctrine of the rule of law, certain historical prerequisites for the emergence of the principle of the rule of law and its application in the practice of the European Court of Human Rights have been studied by such scholars as S. Golovaty, K. Gubarev, A. Daisi, M. Denisyuk, A. Karas, O. Krizhov, L. Makarenko, R. Padalka, A. Pukhtetska V. Shilling and many other scientists.

Setting objectives. The purpose of the study is to analyze the case law of the European Court of Human Rights for the formation of the rule of law and its practical implementation. 
Presenting main material. The current legislation of Ukraine states that the principle of the rule of law is applied in the light of the case law of the European Court of Human Rights, let us consider in more detail some cases of such practice.

In general, the rule of law has a long history. Yes, it was formed by adherents of the theory of natural law in the seventeenth and nineteenth centuries, and the term, according to researchers, was introduced into the legal field by English scientist and politician D. Harrington in 1656. In addition, the classic rationale for this concept is described in In 1885, Professor Albert Daisy, a professor at the University of Oxford, in «Introduction to the Study of the Law of the Constitution,» in which he outlined three main components that express the internal «spirit» of the rule of law and which give rise to this concept: a. free government; b) equality before the law; c) constitutional law, which is a consequence of the rights of a person, not their source (K.S. Gubarev, 2006; V. Shillingov, 2009; O. Krizova, 544-549).

As noted by S.P. Headed, there is a three-level normalization of the principle of the rule of law in the system of law, in particular, this principle is present in international treaties - as a norm of international law, which has been implemented in national law (S.P. Golovaty, 2008).

Thus, under Article 3 of the Charter of the Council of Europe, every member of the Council of Europe must necessarily recognize the principles of the rule of law and the enjoyment of human rights and fundamental freedoms by all persons within its jurisdiction, and must cooperate openly and effectively in pursuit of the aim of the Council in Chapter I of the Council of Europe Charter (5).

Also, according to the preamble to the Convention for the Protection of Human Rights and Fundamental Freedoms, the governments of the European states share a common heritage of political traditions, ideals, freedom and the rule of law (6).

As the current legislation of Ukraine states that the rule of law is applied in the light of the case-law of the European Court of Human Rights, let us consider in more detail some cases of such practice.

Thus, the judgment of the European Court of Human Rights in the case of Krusslen v. France, dated 24 April 1990, Series A, No. 176-A, stated that the predictability of the law, that is, the content and nature of the applicable measures, was one of the requirements which included the notion of «in accordance with the law» creates certain problems within this case. As the Court noted in its judgment in the Malone case of 2 August 1984, paragraph 2 of Art. 8 of the Convention contains not only a reference to national law, but also concerns the quality of the law, requiring its conformity with the principle of the rule of law. This means that there must be a remedy in national law against arbitrary interference by public authorities in the rights guaranteed by paragraph $1 \ldots$ The danger of arbitrariness is particularly apparent when the executive is exercising its functions in secret. Undoubtedly, in such a special issue as the interception of communications by means of communications for the purpose of police investigation or judicial investigation, the requirements of the Convention, 
especially as to the predictability of the law, cannot be as they are when the purpose of the relevant law is to create certain restrictions on the actions of individuals. In particular, the requirement of foreseeability cannot mean that a person should be able to anticipate when authorities may intercept his message in order to adjust his actions accordingly. On the other hand, the law should contain sufficiently clear and precise wording that would give citizens a proper understanding of the circumstances and conditions under which public authorities are empowered to resort to this secret and potentially dangerous interference with the right to respect for privacy and correspondence (7; O. Krizova, 544-549).

This makes it possible to understand that all the elements of the rule of law are closely linked. And if legal uncertainty is allowed, it will contribute to the violation of law and arbitrariness, in particular by public service bodies, etc.

Professor S. Holovaty analyzing the decision of the European Court of Human Rights in Bellet v. France, which stated in particular: «In view of the principle of the rule of law in a democratic society, the measure afforded by national law must also be sufficient to ensure that provide the person with a «right to a court». In order for the right of access to be effective (effective), a person must have an unequivocal, real opportunity to challenge an action that interferes with his or her right» (8), notes that in this the ECtHR has developed one of its conclusions, enshrined in one of its previous decisions., stating that a person «should have an unequivocal, real and effective opportunity to challenge an administrative act which was a direct violation of his or her right» (9). In another judgment of the European Court of Human Rights, he emphasized: «based on the rule of law in a democratic society, then the degree of access afforded by national law must also be sufficient to provide a person with a «right to a court» $(10 ; 11)$.

Also among the judgments of the European Court of Human Rights which contain interpretations of the rule of law: Streletz, Kessler and Krenz v. Germany; Salov v. Ukraine; Naumenko v. Ukraine; Sovtransavto-holding against Ukraine and the like.

According to the Law of Ukraine «On Enforcement of Decisions and Application of the Practice of the European Court of Human Rights» (12), the courts of our country apply the practice of the European Court of Human Rights.

In accordance with the resolution of the Cabinet of Ministers of Ukraine «On measures to implement the Law of Ukraine» On Enforcement of Decisions and Application of the Practice of the European Court of Human Rights «of May 31, 2006, No. 784 approved the Regulation on the Government Ombudsman of the European Court of Human Rights (13).

Therefore, as an example, the decision of the Supreme Administrative Court of Ukraine of 11.04.2016 in case No. K / 800/6092/16, in which the court, revealing the principle of the rule of law, refers to the decision of the European Court of Human Rights in the case of Brumarescu v. Romania «dated November 28, 1999. According 
to this decision, the right to a fair trial guaranteed by Article $6 \S 1$ of the Convention should be interpreted in the context of the Preamble to the Convention, which in particular proclaims the rule of law as an integral part of the common heritage of the Contracting States.

One of the fundamental aspects of the rule of law is the principle of legal certainty, according to which, in the event of a final settlement of a dispute by a court, their decision, which has entered into force, cannot be called into question. The principle of legal certainty requires respect for the principle of res judicata, that is, respect for the final judgment. According to this principle, neither party has the right to request that the final and binding decision of the court be reviewed for one purpose only - to seek reconsideration and adjudication of the case (Ryabykh v. Russia, July 24, 2003) (14).

Such an interpretation is certainly fair, but only if an independent court operates, whose activity is based primarily on the rule of law.

It should be noted that in our opinion the interpretation of the «rule of law» in the Judgment of the Constitutional Court of Ukraine No. 15-rp of November 2, 2004, as a rule of law in the society, was stated quite precisely, and specified that the rule of law requires the state to translate it into law-making and law enforcement activities, in particular the laws that, in their content, must be permeated above all by the ideas of social justice, freedom, equality, etc. One of the manifestations of the rule of law is that law is not limited to legislation as one of its forms, but also includes other social regulators, such as norms of morality, traditions, customs, etc., which are legitimized by society and predetermined by the historically attained cultural level of society. All these elements of law are combined by a quality that is consistent with the ideology of justice, the idea of law, which has largely been reflected in the Constitution of Ukraine (15).

Conclusion. Thus, many decisions of the European Court of Human Rights contain interpretations of certain elements of the principle of the rule of law, which must certainly be reflected in the legislation of Ukraine, since, in accordance with the latter, the rule of law is applied in the light of the case law of the European Court of Human Rights.

\section{REFERENCES}

1.Gubarev K.S. (2006). Deiaki istorychni peredumovy vynyknennia pryntsypu verkhovenstva prava. [Some historical prerequisites for the rule of law]. Yurydychnyi zhurnal - Law Journal, 9, 31-39.

2. Shillingov V. (2009). Verkhovenstvo prava - osnovopolozhnyi pryntsyp pravovoi systemy demokratychnoho suspilstva. [The rule of law is a fundamental 
principle of the legal system of a democratic society]. Chasopys Kyivskoho universytetu prava - Journal of the Kyiv University of Law. K., 2, 26-29.

3. Krizova O. Pryntsyp verkhovenstva prava u praktytsi Yevropeiskoho sudu z prav liudyny. [The principle of the rule of law in the practice of the European Court of Human Rights], 544-549. Retrieved from http://science.lpnu.ua/sites/default/ files/journal-paper/2018/jun/13468/84.pdf [in Ukrainian].

4. Golovaty S.P. (2008). Verkhovenstvo prava: Ideia. Doktryna. Pryntsyp [Rule of Law: An Idea. Doctrine. Principle]. Author's abstract. diss. ... Doc. lawyer. Sciences, Kyiv. Retrieved from http://webcache.googleusercontent.com/search?q= cache:jLlWfS_Yv_4J:www.irbisnbuv.gov.ua/cgibin/irbis_low/cgiirbis_64.exe\%3FC21 COM\%3D2\%26I21DBN\%3DARD\%26P21DBN\%3DARD\%26Z21ID\%3D\%26Image _file_name\%3DDOC/2008/08gspidp.zip\%26IMAGE_FILE_DOWNLOAD \%3D1+\&c $\mathrm{d}=1 \& \mathrm{hl}=\mathrm{ru} \& \mathrm{ct}=\mathrm{clnk} \& \mathrm{gl}=\mathrm{ua}$ [in Ukrainian].

5. Ctatut Rady Yevropy vid 5 travnia 1949 r. Zibrannia chynnykh mizhnarodnykh dohovoriv Ukrainy. 2006 r. № 5. (Knyha 2). [Council of Europe Statute of May 5, 1949. Collection of current international treaties of Ukraine. 2006 № 5]. (Book 2). Retrieved from https://zakon.rada.gov.ua/laws/show/994_001 [in Ukrainian].

6. Preambula Konventsii pro zakhyst prav liudyny i osnovopolozhnykh svobod vid 04 lystopada 1950 r. [Preamble to the Convention on the Protection of Liberty and Fundamental Freedoms 04 October 1950 r.]. Ofitsiinyi visnyk Ukrainy (1998), 13, 32, 270. Retrieved from https://zakon.rada.gov.ua/laws/show/995_004 [in Ukrainian].

7. Rishennia Yevropeiskoho sudu $\mathrm{z}$ prav liudyny, sprava «Kruslen proty Frantsii»: vid 24 kvitnia. 1990 r. [Judgment of the European Court of Human Rights in the case of Cruzlin v. France: 24 April. 1990]. Retrieved from http://eurocourt.in. ua/Article.asp?AIdx $=432$ [in Ukrainian].

8. Case of Bellet v. France, 4 December 1995, Series A, No. 333-B, para 36; Case of F. E. v. France, 30 October 1998, Reports of Judgments and Decisions 1998-VIII, para 46.

9. Case of de Geouffre de la Pradelle v. France, 16 December 1992, Series A, No. 253-B, para 34.

10. Case of Yagtzilar and Others v. Greece, no. 41727/98, 6 December 2001, para 26.

11.Verkhovenstvo prava ta prava liudyny u svitli Konventsii pro zakhyst prav liudyny ta osnovopolozhnykh svobod: Praktychno-metodychnyi posibnyk vykladacha / Vydannia zdiisneno za pidtrymky amerykanskoho narodu, nadanoi cherez Ahentstvo SShA z mizhnarodnoho rozvytku (USAID) v ramkakh Proektu «Spravedlyve pravosuddia» (2016). [Rule of Law and Human Rights in the Light of the Convention for the Protection of Human Rights and Fundamental Freedoms: Teacher's Guide / 
Edition published with the support of the American people through the United States Agency for International Development (USAID) as part of the Just Justice Project] [in Ukrainian].

12. Pro vykonannia rishen ta zastosuvannia praktyky Yevropeiskoho sudu z prav liudyny: Zakon Ukrainy [On the enforcement of decisions and the application of the case law of the European Court of Human Rights] (2006). Vidomosti Verkhovnoi Rady (VVR), 3477 [in Ukrainian].

13. Pro zakhody shchodo realizatsii Zakonu Ukrainy «Pro vykonannia rishen ta zastosuvannia praktyky Yevropeiskoho sudu z prav liudyny» [Measures to implement the Law of Ukraine «On Enforcement of Judgments and the Practice of the European Court of Human Rights»] (2006). Postanova Kabinetu Ministriv Ukrainy, 784 Retrieved from http://zakon.rada.gov.ua/laws/show/784-2006-п [in Ukrainian].

14. Rishennia Yevropeiskoho sudu z prav liudyny yak dzherelo prava [Decision of the European Court of Human Rights as a source of law]. Ofitsiinyi veb-sait Vinnytskoho apeliatsiinoho administratyvnoho sudu. Retrieved from http://www.vaas. gov.ua/news/rishennya-yevropejskogo-sudu-z-prav-lyudini-yak-dzherelo-prava/ [in Ukrainian].

15. Rishennya Konstytutsiynoho Sudu Ukrayiny [Judgment of the Constitutional Court of Ukraine] (2004), 15-pп. Retrieved from http://zakon0.rada.gov.ua/laws/ show/v015p710-04 [in Ukrainian]. 